\title{
PERAN CITRA MEREK DALAM MEMEDIASI PENGARUH DAYA TARIK IKLAN TERHADAP NIAT BELI HONDA PCX 150
}

\author{
Putu Anita Fransiska ${ }^{1}$ \\ Ni Ketut Seminari ${ }^{2}$ \\ ${ }^{1,2}$ Fakultas Ekonomi dan Bisnis Universitas Udayana, Bali, Indonesia \\ Email: anitafransiskaputu@yahoo.co.id
}

\begin{abstract}
ABSTRAK
Banyak faktor dapat mempengaruhi niat beli terhadap suatu produk tertentu. Tujuan penelitian adalah menguji peran citra merek dalam memediasi pengaruh daya tarik iklan terhadap niat beli sepeda motor Honda PCX di Kota Denpasar. Jenis penelitian digolongkan ke dalam penelitian asosiatif. Objek didalam penelitian adalah peran citra merek (M) memediasi pengaruh daya tarik iklan (X) terhadap niat beli (Y) sepeda motor Honda PCX 150 di wilayah Denpasar dengan menggunakan sebanyak 105 responden yang ditentukan dengan metode purposive sampling. Pengujian hipotesis dilakukan dengan analisis path dan dilanjutkan dengan uji sobel untuk mengetahui pengaruh mediasi. Hasil analisis menunjukkan bahwa daya tarik iklan berpengaruh signifikan terhadap citra merek. Citra merek berpengaruh positif terhadap niat beli sepeda motor Honda PCX 150. Daya tarik iklan berpengaruh positif terhadap niat beli untuk sepeda motor Honda PCX 150. Citra merek secara siginfikan memediasi hubungan antara daya tarik iklan dengan niat beli konsumen untuk sepeda motor Honda PCX 150.
\end{abstract}

Kata kunci : daya tarik iklan, citra merek, niat beli

\begin{abstract}
Many factors can affect the buying intentions of a particular product. The objective of the research is to test the role of brand image in mediating the influence of ad attraction on PCX motorcycle purchase intention in Denpasar City. This type of research is classified into associative research. The object of the research is the role of brand image (M) mediating the influence of ad attraction $(X)$ on the purchase intention $(Y)$ of Honda PCX 150 motorcycle in Denpasar area using 105 respondents determined by purposive sampling method. Hypothesis testing is done by path analysis and continued with the test of sobel to know the influence of mediation. The results of the analysis indicate that the attractiveness of the advertisement has a significant effect on the brand image. Brand image positively affects the intention to buy Honda PCX 150 motorcycles. Ad appeal positively affects purchasing intentions for Honda PCX 150 motorcycles. Brand image significantly mediates the relationship between ad appeal and consumer purchase intentions for Honda PCX 150 motorcycles.
\end{abstract}

Keyword : ad appeal, brand image, purchase intent 


\section{PENDAHULUAN}

Perkembangan jumlah penduduk yang cukup pesat serta beragamnya aktivitas kerja setiap orang memungkinkan segala aktivitas tersebut dilakukan secara cepat, agar orang dapat melakukan pekerjaan dengan efektif dan efisien, dibutuhkan sarana pendukung seperti transportasi. Transportasi merupakan alat yang berguna untuk memindahkan barang atau orang dalam kuantitas tertentu, ke suatu tempat tertentu. Kota Denpasar merupakan kota yang memiliki jumlah penduduk yang cukup padat sehingga menyebabkan penduduknya memerlukan transportasi yang cepat dan terjangkau. Bermacam-macamnya jenis transportasi yang ada, seperti kendaraan roda empat, kendaraan roda dua (sepeda, dan sepeda motor), angkutan umum dan angkutan online, hal ini menjadi peluang bagi perusahaan yang ingin menjual produknya dan menjadikan Denpasar menjadi pasar sasaran yang potensial.

Salah satu transportasi yang banyak digunakan di Denpasar adalah sepeda motor. Pesatnya pertumbuhan industri sepeda motor di Indonesia di pengaruhi oleh masuknya sejumlah produsen sepeda motor dari luar yang rata-rata berasal dari Jepang. Merek-merek sepeda motor yang selama ini banyak dibeli adalah sepeda motor keluaran Honda, Yamaha, Suzuki, Kawasaki, dan TVS, ada juga merek-merek sepeda motor yang berasal dari negara Italia, India, Amerika, dan Cina yang dipasarkan di Indonesia. Produk keluaran PT Astra Honda Motor merupakan pemimpin pasar di industri sepeda motor di Indonesia. Walaupun Honda mengalami penurunan penjualan pada tahun 2014, namun pada tahun 2015 dan 2016 mulai mengalami peningkatan penjualan. Berdasarkan penjelasan dari 
data Asosiasi Industri Sepeda Motor Indonesia (AISI) 2012-2016, aspek yang harus dimiliki dan dipertahankan, nilai positif bagi setiap perusahaan adalah citra merek, karena pada dasarnya, sebuah merek merupakan alat identitas yang secara spesifik membuat nilai yang menjanjikan baik bagi produsen maupun konsumen.

Tidak ingin kalah dengan produsen lain ditengah persaingan produk sepeda motor bertransmisi otomatis yang semakin kompetitif dari waktu ke waktu, Honda mengeluarkan produk dengan segmen skutermatik untuk memuaskan konsumen. Salah satu varian produk Honda yang baru muncul adalah Honda PCX 150 merupakan motor keluaran Honda yang ditujukan bagi segmen motor premium skutik. Motor matic Honda yang satu ini memang terlihat berbeda pada umumnya, desain yang lebih besar dan lebar menjadikan Honda PCX terlihat semakin sporty dan stylish, terlebih ditunjang dengan aneka pilihan warna solid di body motor. (www.otomotif.com). Varian merek Honda PCX 150 ini bersaing dikelasnya yaitu NMAX sepeda motor keluaran Yamaha. Sepeda motor PCX 150 dijual dengan harga yang relatif lebih mahal dari pada NMAX yaitu Rp. 40.575.000, sedangkan NMAX dijual dengan harga Rp. 30.200.000. Harga PCX yang tinggi disebabkan Astra Honda Motor masih harus mengimpor motor matic tersebut dari Vietnam, sedangkan pesaingnya NMAX sudah diproduksi di Indonesia.

Penjualan sepeda motor Honda PCX 150 mengalami peningkatan penjualan dari tahun 2012 sampai tahun 2013 sebesar 11,68\% sedangkan tahun 2013 sampai 2014 meningkat sebesar 18,50\% namun penjualan sepeda motor Honda PCX 150 mengalami penurunan penjualan secara berturut turut dari tahun 2015 sampai tahun 2016, pada tahun 2015 mengalami penurunan penjualan sebesar 9,48\% dan 
pada tahun 2016 sebesar 9,05\%. Menurunnya penjualan sepeda motor Honda PCX 150 maka hal ini menunjukkan bahwa niat beli konsumen terhadap Honda PCX 150 menurun. Sebagai varian produk baru Honda PCX 150 harus lebih gencar melakukan periklanan guna meningkatkan citra merek sehingga dapat meningkatkan niat beli terhadap Honda PCX 150.

Niat beli adalah tahap konsumen dalam membentuk pilihan mereka diantara beberapa merek yang tergabung dalam perangkat pilihan, kemudian pada akhirnya melakukan suatu pembelian pada suatu alternatif yang disukainya atau proses yang dilalui konsumen untuk membeli suatu barang dan jasa yang didasari oleh bermacam pertimbangan (Annafik dan Rahardjo, 2012). Niat beli dapat digunakan untuk menganalisis perilaku konsumen, sebelum melakukan pembelian konsumen akan mencari informasi tentang suatu produk, kemudian konsumen akan melakukan penilaian terhadap produk berdasarkan informasi-informasi yang mereka miliki, selanjutnya konsumen akan melakukan perbandingan produk dan melakukan evaluasi serta membuat suatu keputusan pembelian. Banyak faktor dapat mempengaruhi niat beli terhadap suatu produk tertentu. Menurut Sulistyari dan Yoestini (2012), faktor-faktor yang mempengaruhi niat beli adalah citra merek, kualitas produk dan harga. Penelitian ini merupakan pengembangan dari penelitian Sulistyari dan Yoestini (2012) dengan menambahkan variabel daya tarik iklan sesuai penelitian Annafik dan Rahardjo (2012).

Strategi yang digunakan PT Astra Honda Motor dalam rangka meningkatkan niat beli konsumen adalah dengan melakukan promosi, antara lainya melalui media periklanan. Iklan merupakan semua bentuk terbayar 
presentasi non pribadi dan promosi ide, barang, atau jasa dengan sponsor tententu (Kotler dan Armstrong 2008:117). Iklan harus berani menawarkan suatu kreativitas, agar dimata konsumen terlihat berbeda atau unik dari iklan-iklan yang lainnya, dalam penyampaian pesan iklan harus jelas dan terarah, agar dapat menciptakan daya tarik tersendiri terhadap produk yang diiklankan tersebut (Annafik dan Rahardjo, 2012). Iklan yang menarik dan kreatif tentunya menarik minat konsumen untuk membeli produk tersebut. Iklan dilakukan untuk memasarkan produk baru, memasuki segmen pasar yang baru atau tidak terjangkau oleh salesman atau personal selling (Daryanto, 2013).

Salah satu media iklan yang digunakan Honda PCX 150 melalui media televisi, iklan Honda PCX 150 yang memiliki slogan "My Signature" memiiliki ide yang kreatif yang dapat menyadarkan konsumennya bahwa pada era teknologi seperti sekarang bukan hanya memiliki kendaraan sepeda motor saja itu sebenarnya konsumen membeli produk dengan memberikan kesempurnaan dalam menggunakan kendaraan sepeda motor. Visualisasi yang ditampilkan dalam iklan tersebut juga menarik, menggambarkan bagaimana konsumen mengendarai sebuah sepeda motor yang sempurna dari fitur serta kenyamanan dalam berkendaraan sepeda motor, disentuh dengan grafik-grafik pengambilan gambar yang sangat luar biasa yang mengajak konsumen merasakan langsung dari terpaan iklan tersebut. Penggunaan media iklan diharapkan dapat menarik perhatian konsumen dan juga dapat meningkatkan citra merek dari produk tersebut. (Azhar dan Widyastuti 2014). Penelitian ini menarik untuk dilakukan karena daya tarik iklan yang dimediasi oleh citra merek dari produk Honda diasumsikan memiliki 
peran yang signifikan dalam mempengaruhi timbulnya niat beli konsumen terhadap produk sepeda motor Honda PCX 150.

Tujuan dari pelitian ini adalah, (1) untuk menjelaskan pengaruh daya tarik iklan terhadap citra merek sepeda motor Honda PCX 150; (2) untuk menjelaskan pengaruh daya tarik iklan terhadap niat beli sepeda motor Honda PCX 150; (3) untuk menjelaskan pengaruh citra merek terhadap niat beli sepeda motor Honda PCX 150; (4) untuk menjelaskan peran citra merek dalam memediasi pengaruh daya tarik iklan terhadap niat beli sepeda motor Honda PCX 150.

Penelitian ini mempunyai kegunaan sebagai berikut, Hasil penelitian ini secara teoritis diharapkan memberi sumbangan empiris tentang peran citra merek dalam memediasi pengaruh daya tarik iklan terhadap niat beli, sehingga dapat digunakan sebagai refrensi untuk melakukan studi selanjutnya. Hasil penelitian juga diharapkan dapat memberikan informasi yang berharga bagi perusahaan terutama dalam hal meningkatkan penjualan sepeda motor, serta sebagai bahan pertimbangan untuk mengevaluasi, memperbaiki, dan meningkatkan kinerja manajemen di masa yang akan datang.

Kotler dan Armstrong (2016:275) menyatakan bahwa brand are more than just name and symbols. They are a key element in the company's relationship with consumers atau merek lebih dari sekedar nama dan simbol, merek adalah elemen kunci dalam hubungan antara perusahaan dengan pelanggan. Citra merek adalah salah satu bagian dari ekuitas merek. Kotler dan Keller (2016:330) menyatakan bahwa brand imagery:decribes the extrinsic properties of the product/ services including the wasy in which the brand attempts to meet costumers' psychological 
or social needs atau menjelaskan sifat ekstrinsik dari produk/ jasa termasuk cara dimana merek mencoba untuk memenuhi kebutuhan psikologi atau sosial pelanggan. Dapat disimpulkan bahwa citra merek adalah persepsi seseorang dari sekumpulan asosiasi terhadap sebuah merek. Semakin baik persepsi seseorang terhadap sebuah merek maka dapat dikatakan bahwa citra merek mengenai merek tersebut telah berhasil dibangun. Sebaliknya, apabila persepsi seseorang terhadap sebuah merek tersebut buruk atau negatif maka dapat dikatakan brand image mengenai suatu merek telah gagal dibangun.

Menurut Ralph (dalam Morissan 2010: 17), iklan atau advertising dapat didefinisikan sebagai "any paid form nonpersonal communication about an organization, product, service, or idea by an idenified sponsor" atau setiap bentuk komunikasi non pesonal mengenai suatu organisasi, produk, servis, atau ide yang harus dibayar oleh sponsor yang diketahui. Adapun maksud 'dibayar' pada difinisi tersebut menunjukkkan fakta bahwa ruang atau waktu bagi suatu pesan iklan pada umumnya harus dibeli. Rahma (2007) dalam Maksoaka dan Rahyuda 2016 menyatakan niat yang muncul dalam melakukan pembelian menciptakan suatu motivasi yang terus terekam dalam benaknya dan menjadi suatu kegiatan yang sangat kuat pada akhirnya ketika seorang konsumen harus memenuhi kebutuhannya akan mengaktualisasikan apa yang ada dalam benaknya itu, dapat disimpulkan bahwa niat beli merupakan suatu motivasi yang timbul dari dalam diri seseorang, apakah berniat untuk membeli suatu produk atau tidak.

Sasetyo et al. (2012), yang melakukan penelitian pada produk Pepsodent menyatakan bahwa daya tarik iklan memiliki pengaruh yang tinggi dan kuat 
Putu Anita Fransiska, Peran Citra Merek Dalam Memediasi...

terhadap pembentukan citra merek. Hasil penelitian Azhar dan Widyastuti (2014) menunjukkan bahwa daya tarik iklan memiliki hubungan positif dengan brand image secara langsung. Berdasarkan uraian diatas dapat disimpulkan bahwa hipotesis penelitaian adalah sebagai berikut:

$\mathrm{H}_{1}$ : Daya tarik iklan berpengaruh positif dan signifikan terhadap citra merek.

Citra merek terdiri dari atribut dan manfaat yang terkait dengan merek tersebut kemudian membuat merek menjadi khas, sehingga membedakan tawaran perusahaan dari persaingan (Webster dan Keller. 2004 dalam Jailvand. et,al 2011), sehingga dengan citra merek yang kuat mampu mempengaruhi niat beli seseorang. (Torlak. et,al 2014 dalam elseidi. et,al 2016) menyimpulkan bahwa brand image merupakan pendorong utama, yang secara positif mempengaruhi niat pembelian pemesanan hotel. Berdasarkan uraian diatas dapat disimpulkan bahwa hipotesis penelitian adalah sebagai berikut:

$\mathrm{H}_{2}$ : Citra merek berpengaruh positif dan signifikan terhadap niat beli.

Penelitin Azhar dan Widyastuti (2014) menunjukkan bahwa daya tarik iklan memiliki hubungan positif dan signifikan terhadap niat beli secara langsung. Menurut Parmin (2013) menyatakan bahwa daya tarik iklan berpengaruh signifikan terhadap minat beli konsumen Teh Celup Sari Wangi di Kecamatan Adimulyo. Penelitian Suharto. et, al (2016) menyatakan bahwa daya tarik iklan secara parsial berpengaruh terhadap minat beli konsumen pada PT. Remaja Jaya Mobilindo Manado. Penelitian Amilia, Kardinal dan Megawati (2016) menyatakan bahwa daya tarik iklan berpengaruh positif dan signifikan terhadap 
minat beli konsumen pada situs Tokopedia.com. Berdasarkan uraian diatas dapat disimpulkan bahwa hipotesis penelitian adalah sebagai berikut:

$\mathrm{H}_{3}$ : Daya tarik iklan berpengaruh positif dan signifikan terhadap niat beli.

Menurut penelitin Azhar dan Widyastuti (2014) brand image secara positif dan signifikan dapat memediasi daya tarik iklan terhadap niat beli produk fresh care. Penelitian Fitriana (2013) menyatakan bahwa daya tarik iklan berpengaruh terhadap niat beli melalui citra merek. Hasil penelitian Parmin (2013) menyatakan daya tarik iklan, kualitas produk, dan citra merek berpengaruh terhadap minat beli Konsumen Teh Celup Sariwangi di Kecamatan Adimulyo. Berdasarkan uraian diatas dapat disimpulkan bahwa hipotesis penelitian adalah sebagai berikut:

$\mathrm{H}_{4}$ : Peran citra merek secara positif dan signifikan memediasi pengaruh daya tarik iklan terhadap niat beli.

\section{METODE PENELITIAN}

Jenis penelitian ini digolongkan ke dalam penelitian asosiatif yaitu, penelitian yang bertujuan untuk mengetahui hubungan antara dua variabel atau lebih (Sugiyono, 2014:55). Penelitian ini menguji hipotesis yang menjelaskan pengaruh daya tarik iklan terhadap citra merek, pengaruh daya tarik iklan terhadap niat beli, pengaruh citra merek terhadap niat beli serta peran citra merek dalam memediasi pengaruh daya tarik iklan terhadap niat beli. Lokasi penelitian dilakukan di Kota Denpasar, lokasi ini dipilih karena kota Denpasar merupakan pusat perekonomian di Bali, selain itu Kota Denpasar juga merupakan pusat bisnis, pusat pendidikan, dan di wilayah yang cukup padat dan mempunyai jalanan yang kecil sehingga menyebabkan masyarakat membutuhkan sarana 
Putu Anita Fransiska, Peran Citra Merek Dalam Memediasi...

transportasi seperti sepeda motor. Penelitian ini dilakukan pada konsumen yang belum menggunakan produk Honda PCX 150 di kota Denpasar. Objek didalam penelitian ini adalah peran citra merek (M) memediasi pengaruh daya tarik iklan (X) terhadap niat beli (Y) sepeda motor Honda PCX 150 di Kota Denpasar.

Variabel Independent $(\mathrm{X})$, dalam penelitian ini yaitu daya tarik iklan. Daya tarik iklan adalah segala bentuk penyajian dan promosi ide, barang atau jasa secara non-personal oleh suatu sponsor tertentu yang memerlukan pembayaran , Simarantha (2016). Diukur dengan indikator sebagai berikut: 1) Pesan iklan: Pesan yang disampaikan iklan sepeda Motor Honda PCX 150 sangat jelas. 2) Desain iklan : Tampilan iklan sepeda motor Honda PCX 150 sangat menarik. 3) Naskah iklan : Slogan sepeda motor Honda PCX “My Signature” sangat menarik. 4) Model iklan : Bintang iklan yang dipilih dapat menarik saya untuk membeli sepeda motor Honda PCX 150. 5) Warna dan musik : Konsep perpaduan warna yang digunakan pada iklan sepeda motor Honda PCX 150 sudah mewakili karakter produk. Musik yang enerjik mendukung iklan sepeda motor Honda PCX 150.

Variabel Mediasi atau variabel Intervening (M), dalam penelitian ini yaitu citra merek. Citra merek adalah persepsi mengenai sebuah merek yang melekat dalam benak konsumen, Dipa (2012). Diukur dengan menggunakan indikator sebagai berikut: 1) Kesan Profesional: merek sepeda motor Honda PCX 150 sudah dikenal banyak orang, merek sepeda motor Honda PCX 150 memberikan kesan positif kepada konsumen dan sepeda motor Honda memiliki kualitas unggul disetiap produknya. 2) Kesan modern: sepeda motor Honda PCX 
150 diproduksi di pabrik yang berteknologi tinggi dan sepeda motor Honda PCX 150 selalu melakukan inovasi. 3) Melayani semua segmen: sepeda motor Honda PCX 150 dapat memenuhi kebutuhan semua kalangan.

Variabel Dependen (Y) dalam penelitian ini yaitu niat beli. Niat beli merupakan sebuah perilaku konsumen dimana konsumen mempunyai keinginan dalam memilih, menggunakan, dan mengkonsumsi atau bahkan menginginkan suatu produk yang ditawarkan. Azhar dan Widyastuti (2014). Diukur dengan indikator sebagai berikut: 1) Minat transaksional: saya mempunyai keinginan untuk segera membeli sepeda motor Honda PCX 150 dan saya sangat tertarik untuk memiliki sepeda motor Honda PCX 150. 2) Minat eksploratif: saya akan mengumpulkan informasi sebanyak mungkin sebelum membeli sepeda motor Honda PCX 150.

Data kuantitatif yang dikumpulkan dalam penelitian ini adalah data berdasarkan jenis kelamin, usia, status pekerjaan, jenis pekerjaan, pendidikan terakhir, pendapatan, dan data penjualan sepeda motor Honda yang diperoleh dari Web AISI. Data kualitatif yang dikumpulkan adalah data mengenai gambaran umum perusahaan sepeda motor Honda. Sumber primer dalam penelitian ini adalah responden dan jawaban melalui hasil koesioner. Sedangkan sumber sekunder dalam penelitian ini yaitu data penjualan sepeda motor Honda yang diperoleh dari Web AISI, 2012-2016.

Populasi dalam penelitian ini adalah para konsumen yang belum memakai sepeda motor Honda PCX 150 ataupun yang berniat membeli sepeda motor Honda PCX 150. Dalam penelititian ini, metode penentuan sampel yang 
digunakan adalah non probability sampling yaitu teknik pengambilan sampel yang tidak memberi peluang atau kesempatan yang sama bagi setiap unsur atau anggota populasi untuk dipilih menjadi sampel (Effendi and Tukiran, 2012:157).

Teknik non probability sampling yang dipilih adalah Purposive Sampling yaitu teknik penentuan sampel dengan pertimbangan tertentu. Adapun kriteria dari penentuan sampel dalam penelitian ini adalah: 1) Usia minimal 20 tahun. Kriteria ini dipakai, karena pada umur 20 tahun responden dianggap sudah mampu mengerti isi dari koesioner dan pada usia 20 tahun penggunaan sepeda motor sudah marak dikalangan masyarakat. 2) Belum pernah membeli sepeda motor Honda PCX 150. Kriteria ini dipakai karena penelitian ini membahas mengenai niat beli dari konsumen. 3) Mengetahui informasi mengenai sepeda motor Honda PCX 150.

Penelitian ini menggunakan indikator sehingga menggunakan estimasi berdasarkan jumlah parameter dapat diperoleh ukuran sampel sebesar 15x7=105 responden dimana peneliti menggunakan ukuran 7 kali lebih besar. Pada penelitian ini, sampel yang digunakan adalah sebesar 105 responden. Metode pengumpulan data yang digunakan dalam penelitian ini adalah koesioner. Kuesioner merupakan teknik pengumpulan data yang dilakukan dengan cara memberikan daftar pertanyaan tertulis kepada para responden untuk dijawab, baik pertanyaan yang sifatnya tertutup maupun terbuka. Bentuk dari koesioner juga bermacam-macam bisa melalui surat lampiran ataupun melalui internet, biasanya koesioner baik digunakan apabila jumlah responden yang digunakan cukup besar 
dan tersebar di berbagai wilayah. Skala penelitian yang digunakan dalam penelitian ini adalah skala Likert.

Analisis statistik deskriptif yaitu suatu statistik yang dipakai untuk menganalisa sebuah data dengan mendeskripsikan atau juga bisa dengan cara mengambarkan data, yang berkaitan dengan karakteristik variabel penelitian yaitu, nilai rata-rata, standar deviasi, varian, nilai minimum, tabel frekuensi, karakteristik responden, rata-rata hitung dan nilai maksimum (Sugiyono, 2013:207). Teknik analisis inferensial menurut (Sugiyono, 2013:210) adalah proses pengambilan kesimpulan-kesimpulan berdasarkan data sampel yang lebih sedikit menjadi kesimpulan yang lebih umum untuk sebuah populasi. Metode analisis statistik yang digunakan dalam statistik inferensial adalah T-test, Anova, Anacova, Analisis regresi, Analisis jalur (path analysis), Structural equation modelling (SEM). Pada penelitian ini peneliti menggunakan analisis jalur (path analysis).

Teknik CFA ditujukan untuk mengestimasi measurement model, menguji unidimensionalitas dari konstruk-konstruk eksogen dan endogen. Model CFA dari masing-masing variabel penelitian, iklan (X), Citra merek (M), dan niat beli (Y). Korelasi Kaiser Meyer Olkin (KMO) atau Barlett's test pada analisis faktor akan menunjukkan validitas konstruk dari analisis faktor. KMO minimal 0,5 apabila nilai KMO dibawah 0,5 maka menunjukkan bahwa analisis factor tidak dapat digunakan. Faktor dipertimbangkan apabila eigen value bernilai lebih besar dari satu (1) dan varian kumulatifnya minimal 60 persen untuk penelitian-penelitian ilmu social (Latan, 2012:46). 
Penelitian ini memakai teknik analisis jalur atau biasa disebut path analysis. Analisis jalur atau path analysis adalah perluasan dari analisis regresi linier berganda, yaitu pengembangan tersebut merupakan penerapan dari variabel intervening. Variabel intervening itu sendiri adalah variabel yang memediasi hubungan antara suatu variabel dengan variabel lainnya. Analisis jalur tersebut, hanya dapat dipakai apabila telah memenuhi syarat tertentu. Langkah-langkah dalam melakukan pengujan hipotesis yang telah dilakukan dengan memakai analisis jalur atau path analysis yaitu: 1) Membuat diagram jalur dari model penelitian 2) Penghitungan Koefisien Path dan Persamaan Struktural 3) pendugaaan parameter atau juuga disebut dengan perhitungan koefisien path 4) Menghitung Nilai Koefisien Determinasi $\left(\mathrm{R}^{2}\right)$ dan Variabel Error (e) 5) Pengaruh Variabel secara parsial 6) Interpretasi hasil analisis jalur.

Pengujian hipotesis mediasi dapat ditempuh dengan prosedur yang telah dikembangkan oleh (Sobel. 1982) dan dikenal dengan istilah uji Sobel atau biasa disebut dengan Sobel test. Uji sobel atau Sobel test dipakai untuk menguji seberapa kekuatan pengaruh tidak langsung antara variabel daya tarik iklan (X) ke variabel niat beli (Y) melalui variabel citra merek (M). Pengaruh tidak langsung daya tarik iklan (X) terhadap variabel niat beli (Y) melalui variabel citra merek (M) dihitung,dengan cara mengalikan antara koefisien jalur X terhadap M (a), dengan koefisien jalur M terhadap Y (b) atau ab. Standard error dari koefisien a dan b nantinya ditulis dengan huruf atau symbol $S_{a}$ dan $S_{b}$, dan besarnya standard error tidak langsung (indirect effect) $\mathrm{S}_{\mathrm{ab}}$. 


\section{HASIL DAN PEMBAHASAN}

Sebuah instrumen dikatakan valid apabila dapat digunakan untuk mengukur apa yang seharusnya diukur. Pengujian validitas tiap butir pertanyaan atau pernyataan dalam instrumen penelitian ini digunakan analisis item yaitu mengkorelasikan skor tiap item dengan skor total item. Nilai korelasi antar skor item dengan total item kemudian dibandingkan dengan $\mathrm{r}$ kritis. Jika korelasi item terhadap skor total lebih besar dari r kritis $(0,30)$ maka instrumen dikatakan valid. Berdasarkan hasil uji validitas menunjukkan bahwa seluruh pernyataan pada variabel daya tarik iklan, citra merek, dan niat beli memiliki nilai koefisien korelasi dengan skor total seluruh item pernyataan lebih besar dari 0,30, sehingga seluruh indikator tersebut telah memenuhi syarat validitas data dan dapat dinyatakan valid.

Sebuah instrumen yang reliabel adalah instrumen yang digunakan beberapa kali dan tetap ada kesamaan data dalam waktu yang berbeda. Dengan melakukan uji reliabilitas instrumen, suatu alat pengukur dipakai dua kali untuk mengukur gejala yang sama dan hasil pengukuran yang diperoleh relatif konsisten. Pengujian reliabilitas tiap butir pertanyaan atau pernyataan dalam instrumen penelitian ini menggunakan metode Cronbach's Alpha. Instrumen dikatakan reliabel untuk mengukur variabel bila berada di atas angka 0,60. Ketiga instrumen penelitian yaitu variabel daya tarik iklan, citra merek, dan niat beli memiliki koefisien Cronbach's Alpha lebih besar dari 0,60 sehingga seluruh pernyataan tersebut memenuhi syarat reliabilitas instrumen dan dapat dinyatakan reliabel. 
Putu Anita Fransiska, Peran Citra Merek Dalam Memediasi...

Teknik pengumpulan data dilakukan melalui instrumen penelitian berupa kuesioner dengan metode angket, yakni penyebaran kuesioner secara langsung kepada responden untuk dijawab sendiri. Kuesioner yang digunakan terdiri atas pernyataan yang dibuat berdasarkan masing-masing variabel, yaitu: variabel daya tarik iklan, citra merek dan niat beli. Untuk mendeskripsikan penilaian responden mengenai variabel-variabel dalam penelitian perlu dilakukan konversi, di mana jawaban responden digolongkan ke dalam beberapa skala pengukuran dengan kriteria tertentu. Berdasarkan hasil penelitian dapat diketahui tanggapan responden dari masing-masing indikator dari setiap variabel adalah sebagai berikut:

Total rata- rata skor untuk variabel daya tarik iklan sebesar 3,85 termasuk dalam kategori menarik. Nilai rata-rata tertinggi diwakili indikator ke enam yaitu musik yang enerjik mendukung iklan sepeda motor Honda PCX 150 dengan nilai rata-rata sebesar 3,94, sedangkan nilai rata-rata terendah diwakili oleh indikator ketiga yaitu tampilan iklan sepeda motor Honda PCX sangat menarik dengan nilai rata-rata 3,70. Persepsi responden tentang citra merek dengan nilai rata-rata sebesar 3,79 dengan kategori setuju. Persepsi responden tentang citra merek yang memiliki rata-rata tertinggi terdapat pada indikator kedua yaitu merek Sepeda motor Honda PCX 150 memberikan kesan positif kepada konsumen dengan nilai rata-rata sebesar 3,88. Total rata- rata skor untuk variabel niat beli sebesar 3,87 termasuk dalam kategori tinggi. Nilai rata-rata skor tertinggi pada indikator ketiga yaitu mengumpulkan informasi sebanyak mungkin sebelum membeli sepeda motor Honda PCX 150 dengan nilai rata-rata sebesar 3,92 dan rata-rata skor 
terendah pada indikator kedua yaitu responden tertarik untuk memiliki sepeda motor Honda PCX 150 dengan nilai rata-rata 3,83.

Berdasarkan hasil uji normalitas diperoleh nilai test statistic sebesar 0,069 dengan nilai Asymp.Sig (2-tailed) sebesar 0,200 lebih besar dari 0,05. Artinya data yang digunakan dalam penelitian ini merupakan data yang berdistribusi normal. Hasil uji multikolinearitas diperoleh nilai Tolerance pada variabel daya tarik iklan dan citra merek sebesar 0,260 lebih besar dari 0,1 dan nilai Variance Inflamation Factor (VIF) lebih kecil dari 10. Hal ini menunjukkan bahwa data dalam penelitian ini tidak mengalami gejala multikolinearitas. Berdasakan hasil uji heteroskedastisitas diperoleh nilai signifkansi pada variabel bebas lebih besar 0,05, sehingga dapat dijelaskan bahwa data dalam persamaan regresi merupakan data yang terbebas dari gejala heteroskedastisitas.

Pengujian data dilakukan dengan analisis jalur (path analysis), yaitu menguji pola hubungan yang mengungkapkan pengaruh variabel atau seperangkat variabel terhadap variabel lainnya, baik pengaruh langsung maupun pengaruh tidak langsung. Langkah pertama dalam analisis jalur adalah merancang model berdasarkan konsep dan teori. Langkah pertama dalam analisis jalur adalah merancang model berdasarkan konsep dan teori, secara teoritis: 1) Variabel daya tarik iklan (X) berpengaruh terhadap citra merek (M) 2) Variabel daya tarik iklan (X) berpengaruh terhadap niat beli (Y) 3) Variabel daya tarik iklan (X) berpengaruh terhadap niat beli(Y) melalui citra merek (M). 


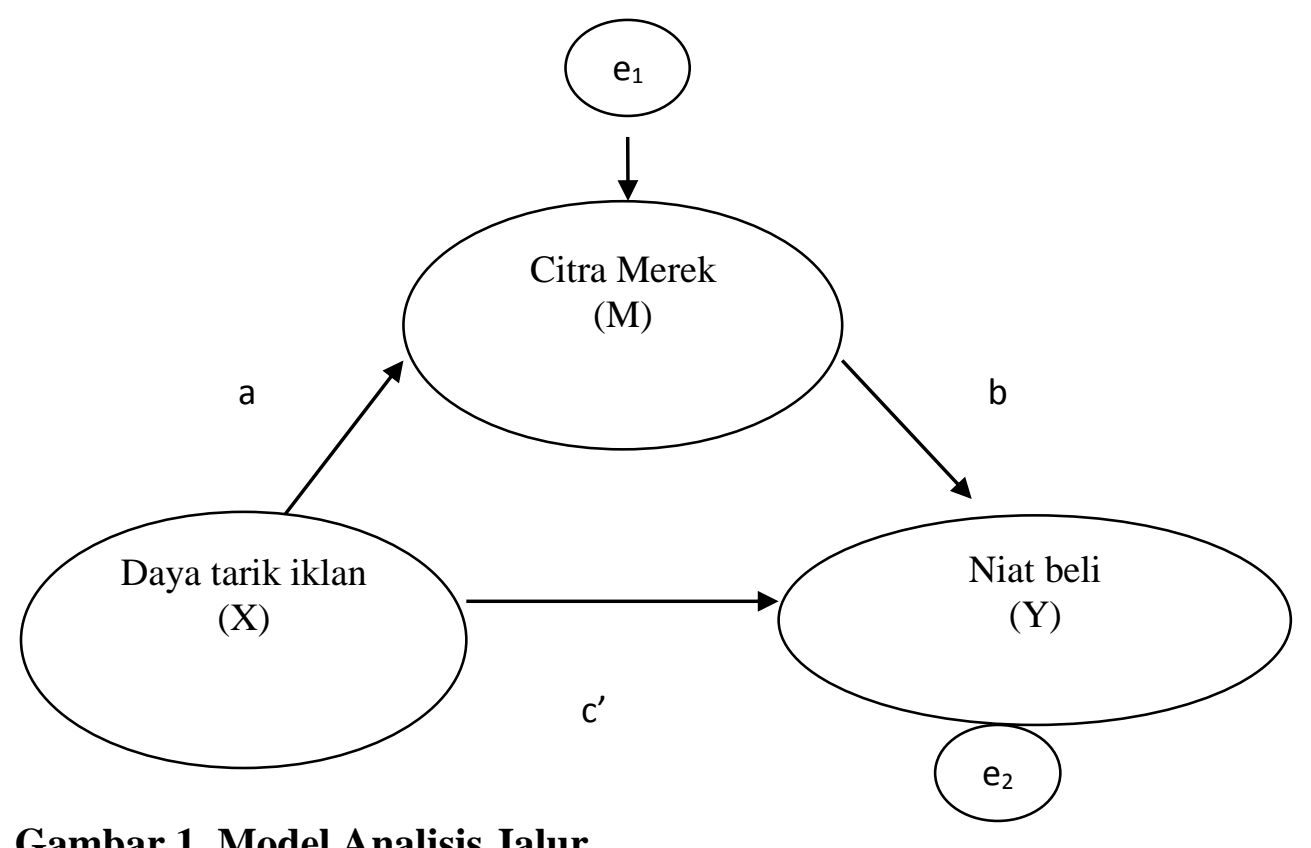

Gambar 1. Model Analisis Jalur

Sumber: Data Diolah, 2017

Model tersebut juga dapat dinyatakan dalam bentuk persamaan struktural sehingga membentuk sistem persamaan sebagai berikut.

Substruktur 1

$\mathrm{Y}=\beta_{0}+\beta_{1} \mathrm{X}+\mathrm{e}_{1}$

Substruktur 2

$M=\beta_{0}+\beta_{2} X+e_{1}$

Substruktur 3

$\mathrm{Y}=\beta_{0}+\beta_{2} \mathrm{X}+\beta_{3} \mathrm{M}+\mathrm{e}_{2}$

Langkah kedua adalah memeriksa asumsi dalam jalur, pemeriksaan terhadap asumsi ini, dapat dilakukan dengan melihat susunan model teoritis yang telah dibangun dengan memperlihatkan bentuk hubungan antar variabel adalah linier, 
yakni sistem aliran ke satu arah, dimana hubungan antara ci saling bebas, demikian juga hubungan antara $\varepsilon$ i dengan variabel $\mathrm{X}$ saling bebas, dan tidak ada variabel endogen yang mempunyai pengaruh bolak balik. Langkah ketiga didalam analisis jalur adalah pendugaan parameter atau perhitungan koefesien path. Untuk pendugaan parameter dilakukan dengan software SPSS for windows. Hasil dari analisis substruktur persamaan dapat disajikan sebagai berikut:

Tabel 1.

Hasil Analisis Jalur Struktur 1

\begin{tabular}{lccrr}
\hline \multicolumn{1}{c}{ Variabel } & $\begin{array}{c}\text { Koefisien } \\
\text { Regresi }\end{array}$ & $\begin{array}{c}\text { Standardized } \\
\text { Coefficients }\end{array}$ & t & Signifikansi \\
\hline \multicolumn{1}{c}{ Daya Tarik Iklan } & 0,92 & 0,86 & 17,104 & 0 \\
\hline Konstanta & & & & $\mathbf{1 , 4 9 6}$ \\
F Hitung & & & & $\mathbf{2 9 2 , 5 3 3}$ \\
Signifikansi & & & & $\mathbf{0}$ \\
R & & & & $\mathbf{0 , 8 6}$ \\
Adjusted & $\mathbf{R}_{1}$ & & & $\mathbf{0 , 7 4}$ \\
Square & & & &
\end{tabular}

Sumber: Data Diolah, 2017

Berdasarkan hasil perhitungan pada Tabel 1 diperoleh persamaan:

Substruktur 1

$\mathrm{Y}=\beta_{0}+\beta_{1} \mathrm{X}+\mathrm{e}_{1}$

$\mathrm{Y}=1,496+0,920 \mathrm{X}+\mathrm{e}_{1}$

$$
\begin{aligned}
\operatorname{Error} \operatorname{Term}\left(\mathrm{e}_{1}\right) & =\sqrt{1-R^{2}} \\
& =\sqrt{1-0,740} \\
& =\sqrt{0,26} \\
& =0,510
\end{aligned}
$$

Berdasarkan hasil perhitungan pada Tabel 2 diperoleh persamaan : 
Substruktur 2

$$
\begin{aligned}
\mathrm{Y}=\beta_{0}+\beta_{1} \mathrm{X}+\beta_{2} \mathrm{M} & +\mathrm{e}_{2} \\
\mathrm{Y}=0,931+0,141 \mathrm{X} & +0,32 \mathrm{M}+\mathrm{e}_{2} \\
\operatorname{Error} \operatorname{Term}\left(\mathrm{e}_{2}\right) & =\sqrt{1-R^{2}} \\
& =\sqrt{1-0,769} \\
& =\sqrt{0,231} \\
& =0,401
\end{aligned}
$$

Lalu untuk hasil analisis jalur kedua akan ditampilkan pada tabel berikut:

Tabel 2.

Hasil Analisis Jalur Struktur 2

\begin{tabular}{lcccr}
\hline \multicolumn{1}{c}{ Variabel } & Koefisien Regresi & Standardized Coefficients & T & Signifikansi \\
\hline Daya Tarik Iklan & 0,141 & 0,259 & 2,782 & 0 \\
Citra Merek & 0,326 & 0,644 & 6,914 & \multicolumn{1}{c}{0} \\
\hline Konstanta & & & $\mathbf{0 , 9 3 1}$ \\
F Hitung & & & $\mathbf{1 7 0 , 1 6 2}$ \\
Signifikansi & & & $\mathbf{0}$ \\
R $_{\mathbf{1}}$ & & & $\mathbf{0 , 8 7 7}$ \\
Adjusted $\mathbf{R}_{\mathbf{1}}$ Square & & & $\mathbf{0 , 7 6 9}$ \\
\hline Sumber: Data Diolah, 2017 & & &
\end{tabular}

Berdasarkan Summary dan Koefisien Jalur 1 dan 2 maka dapat diketahui besarnya pengaruh langsung, pengaruh tidak langsung dan pengaruh total antar variabel. Pengaruh langsung variabel daya tarik iklan terhadap variabel citra merek dapat dilihat dari nilai beta atau Standardized Coefficient, Nilai sebesar 0,860 memiliki arti bahwa pengaruh langsung variabel daya tarik iklan terhadap variabel citra merek adalah sebesar $86 \%$. Nilai sebesar 0,259 memiliki arti bahwa pengaruh langsung variabel daya tarik iklan terhadap variabel niat beli adalah sebesar 25,9\%. Nilai sebesar 0,644 memiliki arti bahwa pengaruh langsung 
variabel citra merek terhadap variabel niat beli adalah sebesar 64,4\%. Nilai sebesar 0,167 memiliki arti bahwa pengaruh tidak langsung daya tarik iklan terhadap niat beli melalui variabel citra merek sepeda motor Honda PCX 150 adalah sebesar 0,167 atau $16,7 \%$. Pengaruh total daya tarik iklan terhadap citra merek dan niat beli sepeda motor Honda PCX 150 adalah sebesar 0,927 atau 92,7\%. Berarti niat beli sepeda motor Honda PCX 150 sebesar 92,7\% dipengaruhi oleh daya tarik iklan melalui citra merek.

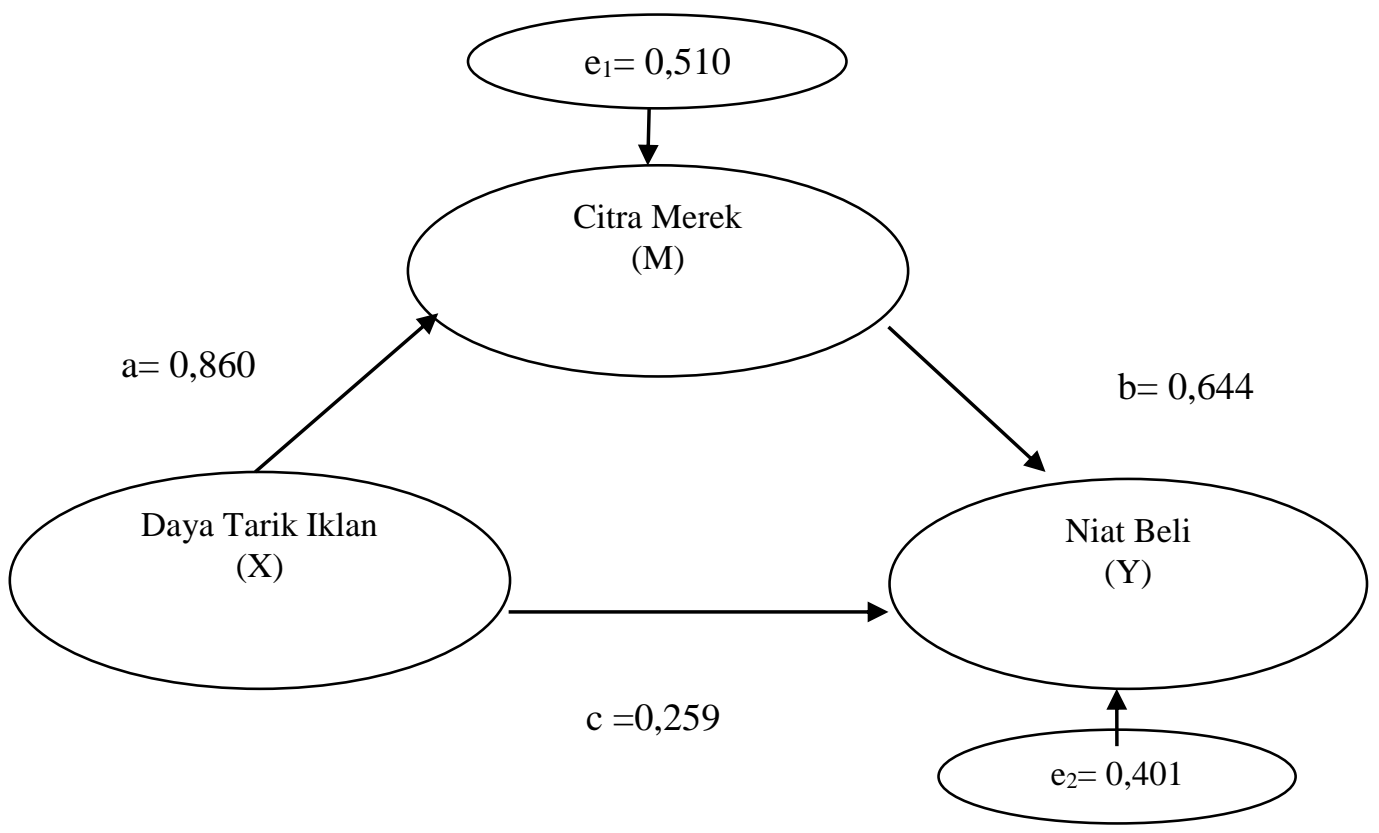

\section{Gambar 2. Validasi Model Gambar Jalur Akhir}

Sumber: Data Diolah, 2017

Hasil perhitungan menunjukkan taraf signifikansi sebesar $0,000 \leq 0,05$, maka $\mathrm{H}_{0}$ ditolak dan $\mathrm{H}_{1}$ diterima. Hal ini berarti terdapat pengaruh positif daya tarik iklan terhadap citra merek. Besar pengaruh yang diperoleh adalah 0,860 . Angka ini menunjukkan bahwa daya tarik iklan memiliki pengaruh signifikan terhadap citra merek sebesar $86 \%$, sedangkan $14 \%$ dipengaruhi oleh faktor di luar model. Berpengaruh signifikan dapat diartikan bahwa apabila daya tarik iklan 
sepeda motor Honda PCX 150 semakin baik, maka persepsi citra merek pada sepeda motor Honda PCX 150 akan semakin meningkat pula. Hasil perhitungan menunjukkan taraf signifikansi sebesar $0,000 \leq 0,05$, maka $\mathrm{H}_{0}$ ditolak dan $\mathrm{H}_{1}$ diterima. Hal ini berarti terdapat pengaruh positif citra merek terhadap niat beli. Besar pengaruh yang diperoleh adalah 0,644. Angka ini menunjukkan bahwa daya citra merek memiliki pengaruh signifikan terhadap niat beli sebesar 64,4\%, sedangkan 35,6\% dipengaruhi oleh faktor di luar model. Berpengaruh signifikan dapat diartikan bahwa apabila citra merek sepeda motor Honda PCX 150 meningkat, niat untuk membeli sepeda motor Honda PCX 150 juga mengalami peningkatan.

Hasil perhitungan menunjukkan taraf signifikansi sebesar $0,006 \leq 0,05$, maka $\mathrm{H}_{0}$ ditolak dan $\mathrm{H}_{1}$ diterima. Hal ini berarti terdapat pengaruh positif daya tarik iklan terhadap niat beli. Besar pengaruh yang diperoleh adalah 0,259. Angka ini menunjukkan bahwa daya tarik iklan memiliki pengaruh signifikan terhadap niat beli sebesar $28,9 \%$, sedangkan $71,1 \%$ dipengaruhi oleh faktor di luar model. Berpengaruh signifikan dapat diartikan bahwa apabila daya tarik iklan sepeda motor Honda PCX 150 semakin tinggi, maka pelanggan akan dapat semakin percaya pada sepeda motor Honda PCX 150. Berdasarkan hasil pengujian sobel dapat disimpulkan bahwa citra merek secara siginfikan memediasi hubungan antara daya tarik iklan dengan niat beli untuk sepeda motor Honda PCX 150. Dalam hal ini terjadi perfect atau complete mediation. Pengaruh daya tarik iklan terhadap niat beli pada sepeda motor Honda PCX 150 sepenuhnya dimediasi oleh citra merek. 
Hasil perhitungan menunjukkan taraf signifikansi sebesar $0,000 \leq 0,05$, maka $\mathrm{H}_{0}$ ditolak dan $\mathrm{H}_{1}$ diterima. Hal ini berarti terdapat pengaruh positif dan signifikan daya tarik iklan terhadap citra merek. Besar pengaruh yang diperoleh adalah 0,860. Angka ini menunjukkan bahwa daya tarik iklan memiliki pengaruh signifikan terhadap citra merek sebesar $86 \%$, sedangkan $14 \%$ dipengaruhi oleh faktor di luar model. Berpengaruh signifikan dapat diartikan bahwa apabila daya tarik iklan sepeda motor Honda PCX 150 semakin baik, maka persepsi citra merek pada sepeda motor Honda PCX 150 akan semakin meningkat pula.

Hasil perhitungan menunjukkan taraf signifikansi sebesar $0,000 \leq 0,05$, maka $\mathrm{H}_{0}$ ditolak dan $\mathrm{H}_{1}$ diterima. Hal ini berarti terdapat pengaruh positif citra merek terhadap niat beli. Besar pengaruh yang diperoleh adalah 0,644. Angka ini menunjukkan bahwa daya citra merek memiliki pengaruh signifikan terhadap niat beli sebesar 64,4\%, sedangkan 35,6\% dipengaruhi oleh faktor di luar model. Hasil perhitungan yang menunjukkan bahwa terdapat hubungan positif yang ditimbulkan dari citra merek terhadap niat beli konsumen, dimana peningkatan yang ditimbulkan dari citra merek yang positif yang dimiliki sepeda motor Honda mengakibatkan peningkatan niat beli sehingga semakin tinggi citra merek maka semakin tinggi pula niat beli sepeda motor Honda PCX 150 di Kota Denpasar. Hasil penelitian ini sejalan dengan penelitian yang dilakukan Elseidi. et,al (2016) menyimpulkan bahwa brand image merupakan pendorong utama, yang secara positif mempengaruhi niat pembelian pemesanan hotel.

Hasil perhitungan menunjukkan taraf signifikansi sebesar $0,006 \leq 0,05$, maka $\mathrm{H}_{0}$ ditolak dan $\mathrm{H}_{1}$ diterima. Hal ini berarti terdapat pengaruh positif daya 
tarik iklan terhadap niat beli. Besar pengaruh yang diperoleh adalah 0,259. Angka ini menunjukkan bahwa daya tarik iklan memiliki pengaruh signifikan terhadap niat beli sebesar $28,9 \%$, sedangkan $71,1 \%$ dipengaruhi oleh faktor di luar model Daya tarik iklan berpengaruh positif terhadap niat beli untuk sepeda motor Honda PCX 150 di Kota Denpasar. Artinya daya tarik iklan yang semakin baik pada sepeda motor Honda PCX 150 dapat meningkatkan niat beli, sehingga semakin tinggi daya tarik iklan yang maka semakin meningkat pula niat beli sepeda motor Honda PCX 150 tersebut. Hasil penelitian ini sejalan dengan penelitian yang dilakukan Suharto. et, al (2016) yang menyatakan bahwa semakin kuat daya tarik Iklan maka semakin tinggi pula niat beli beli konsumen pada PT. Remaja Jaya Mobilindo Manado. Amilia, Kardinal dan Megawati (2016) menyatakan bahwa daya tarik iklan berpengaruh positif dan signifikan terhadap minat beli konsumen. Ilona (2013) meyatakan bahwa daya tarik iklan televisi berpengaruh positif dan signifikan terhadap terhadap minat beli.

Pengujian hipotesis pada peran citra merek dalam memediasi pengaruh daya tarik iklan sepeda motor Honda PCX 150 di Kota Denpasar mendapatkan hasil bahwa bahwa citra merek mampu memediasi daya tarik iklan terhadap niat beli sepeda motor Honda PCX 150 di Kota Denpasar, ini berarti citra merek memediasi pengaruh daya tarik ilan terhadap niat beli secara parsial, dengan kata lain, citra merek memperkuat pengaruh daya tarik iklan ke niat beli yang semula bernilai 0,259 , namun setelah adanya citra merek sebagai variabel mediasi pengaruh daya tarik iklan terhadap niat beli meningkat menjadi 0,644 . Hasil penelitian ini sejalan dengan penelitian yang dilakukan Fitriana (2013) menyatakan bahwa daya tarik iklan berpengaruh terhadap niat beli melalui citra merek. 


\section{SIMPULAN DAN SARAN}

Berdasasarkan hasil pembahasan penelitian dengan analisis jalur yang telah dilakukan, maka dapat disimpulkan bahwa: 1) Daya tarik iklan berpengaruh positif terhadap citra merek sepeda motor Honda PCX 150 di Kota Denpasar. Artinya daya tarik iklan yang tinggi pada sepeda motor Honda PCX 150 dapat meningkatkan citra merek, sehingga semakin tinggi daya tarik iklan, maka semakin tinggi citra merek sepeda motor Honda PCX 150 tersebut. 2) Citra merek berpengaruh positif terhadap niat beli sepeda motor Honda PCX 150 di Kota Denpasar. Artinya citra merek yang semakin tinggi pada Honda dapat meningkatkan niat beli sepeda motor Honda PCX 150 sehingga semakin tinggi citra merek maka semakin tinggi pula niat beli. 3) Daya tarik iklan berpengaruh positif terhadap niat beli untuk sepeda motor Honda PCX 150 di Kota Denpasar. Artinya daya tarik iklan yang tinggi pada sepeda motor Honda PCX 150 dapat meningkatkan niat beli, sehingga semakin tinggi daya tarik iklan maka semakin meningkat pula niat beli sepeda motor Honda PCX 150 tersebut. 4) Citra merek secara siginfikan memediasi hubungan antara daya tarik iklan dengan niat beli sepeda motor Honda PCX 150 di Kota Denpasar, dengan kata lain bahwa daya tarik iklan berpengaruh pada niat beli melalui citra merek. Sehingga semakin tinggi daya tarik yang maka semakin tinggi citra merek yang mana hal ini akan meningkatkan niat untuk membeli sepeda motor Honda PCX 150.

Berdasarkan hasil penelitian yang diperoleh, maka saran-saran yang dapat diberikan adalah: 1) Peneliti selanjutnya disarankan untuk melakukan penelitian di luar variabel bebas yang digunakan dalam penelitian ini misalnya kualitas produk dan bauran pemasaran lain yang dapat digunakan untuk meningkatkan niat beli seseorang. 2) Guna meningkatkan niat beli konsumen yang didasarkan citra 
merek yang dimiliki sepeda motor Honda, sebaiknya perusahaan senantiasa menjaga dan terus meningkatkan citra merek yang ada saat ini terutama berkaitan dengan inovasi produk, pada penelitian ini indikator yang memiliki rata-rata terendah adalah sepeda motor Honda PCX 150 selalu melakukan inovasi, sebaiknya perusahaan lebih meningkatkan teknologi dan fitur yang lebih baik dari produk pesaing. 3) Pihak perusahaan sebaiknya lebih gencar melakukan iklan melalui media televisi karena dengan media televisi calon konsumen dapat melihat produk dan keunggulannya, dan untuk mendongkrak penjualan semua varian sepeda motor, hendaknya perusahaan mengiklankan semua varian sepeda motor yang ada. Pada penelitian ini indikator yang memiliki penilaian yang terendah adalah tampilan iklan sepeda motor Honda PCX 150 sangat menarik, sebaiknya perusahaan memperhatikan tampilan iklan dan tampilan iklan di buat lebih menarik sehingga dapat menarik minat masyarakat untuk menyaksikan iklan tersebut.

\section{REFERENSI}

Ambarawati, Miki., Sunarti., Mukhammad Kholid Mawardi. 2015. Pengaruh Citra Merek Terhadap Niat Beli (Suvey Pada Mahasiswa Universitas Brawijaya yang Menggunakan Pasta Gigi Pepsodent). Jurnal Administrasi Bisnis (JAB), Vol.25 No. 1. Hal. 1-7

Amelia, Siti Rida., Kardinal., Megawati. 2016. Pengaruh Daya Tarik Iklan dan Harga Terhadap Minat Beli (Studi Kasus Mahasiswa STIE MDP), Semarang : Universitas STIE MDP.

Annafik, Aldaan Faikar., Mudji Rahardjo. 2012. Analisis Pengaruh Kualitas Produk, Harga, Daya Tarik Iklan terhadap Minat Beli Sepeda Motor Yamaha, Diponegoro Journal Of Management Volume 1, No 2 Tahun 2012, Hal 274-281

Azhar, Phaza Nurul., Widyastuti. 2014. Pengaruh Daya Tarik Iklan Terhadap Niat Beli Produk Fresh Care Melalui Brand Image. Jurnal Ilmu Manajemen, Vol 2 Nomor 4, Oktober 2014, pp.1197-1207 
Chao, Reng Feng \& Ping-Chu Liao. 2016. The Impact of Brand Image and Discounted Price On Puchase Intention In Outlet Mall : Consumer Attitude As Mediator. The Journal of Global Business Management. Volume 12, Number 2, pp. 119-128

Daryanto. 2013. Sari Kuliah Manajemen Pemasaran. Cetakan II. Januari 2013. PT. Sarana Tutorial Nurani Sejahtera. Bandung

Dewa, Chriswardana Bayu. 2015. Pengaruh Country Of Origin Produk Televisi LG Terhadap Niat Beli Konsumen Dengan Equitas Merek Sebagai Variabel Pemediasi. Jurnal Bianglala Informatika, Vol 3 No 1. Hal.74-82

Dipa, Yoga. 2015. Pengaruh Kualitas Pelayanan terhadap Brand Image Restoran Koki Joni Pasta and Turkey Yogyakarta (Studi Kasus pada Konsumen Restoran Koki Joni Pasta and Turkey Yogyakarta). Yogyakarta: Universitas Sanata Dharma.

Effendi, S., and Tukiran. 2013. Metode Penelitian Survei. Edisi Revisi. Jakarta : LP3ES

Elseidi, Reham I \& Dina El - Baz. 2016. Electronic Word of Mouth Effects On Consumer's Brand Attitudes, Brand Image and Puchase Intention: An Empirical Study In Egypt. The Business and Management Review, Volume7 Number 5, pp. 268-276

Evelina, Nela., Handoyo DW, dan Listyorini, Sari. 2012. Pengaruh Citra Merek, Kualitas Produk, Harga, dan Promosi terhadap Keputusan Pembelian Kartu Perdana Telkom Flexi. Diponegoro Journal of Social and Politic. Hal. 1-11

Fitriana, Stella. 2013. Pengaruh Daya Tarik Iklan terhadap Minat Beli yang Dimediasi oleh Citra Merek. Surakarta : Universitas Muhammadiyah Surakarta

Gadhafi, Mohamad. 2015. Pengaruh Electronic Wor-of Mouth On Consumer Purchase Intention: The Perspective Of Gender Differences. International Journal of Electronic Business Management, Vol. 10, No 3, pp. 175-181

Jailvand, Mohammad. \& Neda Samiei. 2012. The Effect of Electronic Word of Mouth on Brand Image and Puchase Intention An Emperial Study in the Automobile Industry in Iran. Marketing Intelligence \& Planning, Vol. No.4, pp.460-467.

Kahle, Lynn R and Chung Hyun Kim. 2006. Creating Images and The Psycology of Marketing Communication. New Jersey: LEA.

Keller, L.L. 1993. Conceptualising, Measuring and Managing Brand Equity. New Jersey: Pearson Education. 
Keller, L. 1993. How to Manage brand equity. Jakarta: Gramedia Pustaka

Kotler, Philip and Armstrong, Gary. 2016. Principles of Marketing (Global Edition). Edisi 15e. England: Pearson

Kotler, Philip dan Kevin Lane Keller. 2016. Marketing Managemen (Global Edition). Edisi 15e. England: Pearson.

Kotler, Philip; Armstrong, Gary. 2008. Prinsip-Prinsip Pemasaran, Jilid 1, Erlangga, Jakarta.

Latan, Hengky. 2012. Stuctural Equation Modeling. Bandung : Alfabeta

Lane, W. Ronald. Karen Whiehil King \& J. Thomas Rusell. 2009. Kleppner's : Prosedur Periklanan. Jakarta : PT Indeks.

Morissan. 2010. Periklanan Komunikasi Pemasaran Terpadu. Jakarta: Kencana.

Malik, Muhammad Ehsan., Ghafoor, Muhammad Mudasar.,Iqbal, Hafiz Kashif, Ali, Qasim., Hunbal, Hira,Noman, Muhammad and Ahmad, Bilal. 2013. Impact of Brand Image and Advertisement on Consumer Buying Behavior. World Applied Sciences Journal 23 (1): 117-122, 2013 ISSN 1818-4952.

Maunaza, Afianka. 2012. Pengaruh Brand Image terhadap Minat Beli Konsumen. (Studi pada Maskapai Penerbangan Lion Air sebagai Low Cost Carrier), Jakarta: Universitas Indonesia.

Parmin. 2013. Analis Pengaruh Daya Tarik Iklan, Kualitas Produk, dan Citra Merek Terhadap Minat Beli Konsumen Teh Celup Sariwangi di Kecamatan Adimulyo. Jurnal Fokus Bisnis, Vol 12 No.1, Juli 2013. Hal. 59-73

Prasasti, Widi. 2014. Pengaruh Celebrity Endorser Terhadap Niat Beli Konsumen : Studi Pada Produk Sticker Aplikasi Jejaring Sosial LINE. Skripsi Fakultas Ekonomi dan Bisnis Universitas Atmajaya Yogyakarta.

Pujiadi, Bambang. 2010. Studi Tentang Pengaruh Citra Merek terhadap Minat Beli melalui Sikap Terhadap Merek (Kasus Pada Merek Pasta Gigi Ciptadent di Semarang). Semarang: Universitas Diponegoro.

Rahma, Eva Sheilla. 2007. Analisis Pengaruh Kualitas Pelayanan dan Citra Merek terhadap Minat Beli dan Dampaknya pada Keputusan Pembelian (Studi pada Pengguna Telepon Seluler Merek Sony Ericson di Kota Semarang), Semarang: Universitas Diponegoro.

Rizky NST, Muhammad Fakru, \& Hanifa Yasin. 2014. Pengaruh Promosi Dan Harga Terhadap Minat Beli Perumahan Obama PT. Nailah Adi Kurnia Sei Mencirim Medan. Jurnal Manajemen dan Bisnis. Vol 4, No 2, ISSN 19637619 
Rosyida, Layla. 2015. Pengaruh Citra Merek, Kualitas Produk, Harga dan Daya Tarik Iklan Terhadap Minat Beli Yamaha Mio di Semarang. Semarang : Universitas Dian Nuswantoro.

Sasetyo, Sapta Adi, dkk., 2012. Pengaruh Daya Tarik Iklan Terhadap Pembentukan Citra Merek Pepsodent. Ejurnal Mahasiswa Universitas Padjajaran, 1 (1): 1-19.

Sangadji, Etta Mamang dan Sopiah. 2013. Perilaku Konsumen: Pendekatan Praktis Disertai Himpunan Jurnal Penelitian. Yogyakarta: C.V Andi Offset.

Sekaran, U. 2006. Research Methods for Business. Jakarta: Salemba Empat.

Simarmata, Binsar. 2016. Pengaruh Citra Merek dan Daya Tarik Iklan Tehadap Keputusan Pembelian Produk Smarthphone VIVO pada Mahasiswa STIE ITMI. Jurnal Ilmiah Integritas, Vol.2 No 1. Hal. 1-18

Sugiyono. 2006. Metode Penelitian Kuantitatif, Kualitatif dan R\&D. Bandung: Alfabeta

Sugiyono. 2013. Metode Penelitian Pendidikan (Pendekatan Kuantitatif, Kualitatif, dan $R \& D)$. Bandung : Alfabeta

Sugiyono. 2014. Metode Penelitian Kuantitatif, Kualitatif, dan Kombinasi (Mixed Methods). Bandung : Alfabeta

Sugiyono. 2016. Metode Penelitian Pendidikan (Pendekatan Kuantitatif, Kualitatif dan R\&D), Bandung : Alfabeta.

Sulistyari, Ikanita Novirina.,Yoestini. 2012. Analisis Pengaruh Citra Merek, Kualitas Produk, dan Harga Terhadap Minat Beli Produk Oriflame (Studi Kasus Mahasiswi Fakultas Ekonomika dan Bisnis Jurusan Manajemen Universitas Diponegoro Semarang). Diponegoro Journal Of Management, Volume 1, Nomor 1. Hal. 1-17

Suharto, Clifen A.A., Tumbel Altje L., Trang Irvan. 2016. Analisis Pengaruh Citra Merek, Harga, dan Daya Tarik Iklan Terhadap Minat Beli Konsumen pada PT. Remaja Jaya Mobilindo Manado. Jurnal EMBA, Vol.4 No 3 September 2016, Hal. 19-22

Tjiptono, Fandy. 2011. Manajemen \& Strategi Merek. Yogyakarta: Penerbit ANDI.

V, Ilona., Oisina Situmeang. 2013. Pengaruh Daya Tarik Iklan Televisi Toko Bagus Terhadap Minat Beli (Survey Pada Warga Kompleks Citra Gran Cluster Central Garden, Cibubur). Jurnal Komunikasi Volume, 10 Nomor 1, Maret 2013. Hal.1-8 
Putu Anita Fransiska, Peran Citra Merek Dalam Memediasi...

Widyatama, Rendra. 2005. Pengantar Periklanan. Jakarta: Buana Pustaka Indonesia.

Wibowo, Ari. 2015. Pengaruh Elektronik Word of Mouth dan Brand Image Terhadap Puchase Intention pada Konsumen Smarthphone Samsung yang berbasis Android. Jurnal Manajemen Pemasaran, Volume 9, No 1. Hal. 7188 